\title{
The reliability and validity of self-reported reproductive history and obstetric morbidity amongst Birth to Ten mothers in Soweto
}

\author{
GTH Ellison, PhD, Social Science Research Unit, Institute of Education, University of \\ London
}
T de Wet, PhD, Department of Development Studies, Rand Afrikaans University KP Matshidze, MPH, Centre for Epidemiological Research in Southern Africa, Medical Research Council

P Cooper, MBBCH, Department of Paediatrics, University of the Witwatersrand Medical School

\section{Abstract}

Objective: To assess whether self-reports of reproductive history and obstetric morbidity provide an accurate basis for clinical decision-making.

Setting, participants and methods: Self-reports of maternal age and reproductive history, together with clinical measurements of five medical disorders, were abstracted from the obstetric notes of 517 mothers whose children were enrolled in the Birth to Ten study. These data were compared to self-reported information collected by interview during the Birth to Ten study.

Findings: The reliability of self-reported age and gravidity was high ( $R=0.810-0.993)$, yet self-reports of previous miscarriages, terminations, premature- and stillbirths were only fairly reliable (Kappa=0.48-0.50). Self-reported diabetes and high blood pressure had specificities of more than $95 \%$ for glycosuria, hypertension and pre-eclampsia. However, the specificity of self-reported oedema for hypertensive disorders and the specificity of self-reported urinary tract infection for STD seropositivity were only around $65 \%$.

Conclusions: The modest reliability and limited validity of self-reported obstetric morbidity undermines the clinical utility of this information.

Recommendations: These results strengthen the case for providing mothers with "Home-based Maternal Records" to facilitate access to accurate obstetric information during subsequent clinical consultations.

\section{Opsomming}

Doelstelling: Om vas te stel of self-aangemelde reproduktiewe geskiedenis en verloskundige morbiditeit 'n akkurate basis vir kliniese besluitneming bied.

Metode: Moeders se selfverklaarde ouderdom en reproduktiewe geskiedenis, plus die kliniese meting van vyf siekteaandoenings is getranskribeer vanaf die verloskundige notas van 517 moeders wie se kinders in die Birth to Ten-studie geregistreer is. Hierdie gegewens is vergelyk met die self-aangemelde inligting wat deur middel van onderhoude verkry is in die Birth to Ten-studie. Resultate: Die betroubaarheid van die selfverklaarde ouderdom en aantal swangerskappe was hoog $(R=0.810$ 0.993), maar self-aanmeldings van vorige miskrame, beeindigings van swangerskappe, en vroee- en doodgeboortes was slegs redelik betroubaar (Kappa $=0.48$ 0.50 ). Self-aangemelde diabetes en hoe bloeddruk het spesifisiteite van meer as $95 \%$ vir glucosuria, hipertensie en pre-eklampsia, maar die spesifisiteit van selfaangemelde edeem vir hipertensie en die spesifisiteit vir self-aangemelde urienweginfeksies vir seksueeloordraagbare seropositiwiteit was net om en by $65 \%$. Gevolgtrekking: Die beskeie betroubaarheid en beperkte geldigheid van self-aangemelde verloskundige morbiditeit ondermyn die kliniese bruikbaarheid van hierdie inligting. Aanbevelings: Die resultate versterk die argument dat moeders "Tuisgebaseerde Moederrekords" by hulle moet hou sodat toegang tot meer akkurate verloskundige inligting in kliniese opvolgbesoeke makliker beskikbaar is.

\section{Introduction}

Self-reported maternal information plays an important role in antenatal care by helping clinicians identify mothers who are at increased risk of poor obstetric outcomes (Carroll et al. 1988; Peoples-Sheps et al. 1991; Essén et al. 1994). Usually these self-reports are the only source of information on sociodemographic and behavioural risk factors, such as maternal age, social support and tobacco consumption (Harris et al. 1997). They may also be the only source of information on clinical risk factors, such as previous reproductive history and 
obstetric morbidity, when medical records are unavailable (Essén et al. 1994).

In general, maternal reports of sociodemographic and behavioural risk factors seem to be very accurate (Tilley et al. 1985; Fox et al. 1989), although prestige bias can undermine the accuracy of sensitive information, such as smoking behavjour (Fox et al. 1989) and past terminations (Joffe and Grisso 1985). Nevertheless, such inaccuracies are less important than poor recall of clinical risk factors, since these play a more important role in the selection of appropriate antenatal and perinatal care (Hall et al. 1980; Essén et al. 1994). Indeed, the accuracy of self-reported obstetric morbidity tends to be poor (Casey et al. 1992), and while maternal reports usually include a greater number of minor symptoms, such as bleeding and vaginal discharge, than their medical records (Joffe and Grisson 1985), mothers often omit more serious conditions and medical interventions (Tilley et al. 1985).

Inaccurate self-reports of obstetric morbidity severely undermine the provision of appropriate maternity care wherever there are inadequate resources for maintaining access to accurate medical records. Despite the introduction of free primary health care for pregnant women (and to some extent, as a result of free care: McCoy 1996; Hutchings et al. 2001) public antenatal services within many of South Africa's urban and peri-urban townships remain fragmented and difficult to coordinate (Yach et al. 1991). The aim of the present study was therefore to assess the reliability and validity of self-reported reproductive history and obstetric morbidity amongst mothers who delivered children at Baragwanath Hospital (subsequently renamed Chris Hani Hospital). Baragwanath Hospital provides specialist maternity services for Soweto and surrounding peri-urban areas, where self-reports of obstetric morbidity are likely to play an important role in the provision of antenatal care. We compared selfreported obstetric morbidity, collected during interviews with the mothers of children enrolled in a longitudinal birth cohort study (Birth to Ten: Yach et al. 1991; Richter et al. 1995), with self-reported data and clinical measurements recorded in their obstetric notes.

\section{Methods}

Birth to Ten is a longitudinal birth cohort study which set out to enrol all singleton births to mothers resident in the SowetoJohannesburg metropole during a 7 -week period from $23^{\text {rd }}$ April to $8^{\text {th }}$ June 1990 (Richter et al. 1995). A total of 5456 singleton births took place over this period, and 2120 of these occurred at Baragwanath Hospital. A subsequent search of the medical records department located obstetric notes for 517 Birth to Ten mothers and these comprise the sample included in the analyses that follow. Antenatal record charts contained within their obstetric notes provided self-reports of: maternal age, gravidity and previous obstetric problems including miscarriages, terminations, premature- and still-births. Clinical measurements of blood pressure, proteinuria and glycosuria taken during routine antenatal care were also recorded on the antenatal record charts, while seropositivity for sexually-transmitted disease (STD) was recorded on the neonatal record charts of any child that had been admitted for postnatal care. These data provided objective measures of five clinical disorders and the putative 'gold standards' against which the va- lidity of self-reported obstetric morbidity could be assessed. All five of these disorders have been identified as important risk factors for poor obstetric outcome in Africa (Mati 1994):

1. Pre-existing (essential) hypertension was defined as a diastolic blood pressure of $90 \mathrm{mmHg}$ or more recorded at booking, during the first visit to the antenatal clinic (after Sweet 1992; Ventura et al. 1992).

2. Pregnancy-induced hypertension $(P I H)$ was defined as a rise in diastolic blood pressure of $20 \mathrm{mmHg}$ or more from that recorded at booking, on at least two occasions during the course of pregnancy (after Ventura et al. 1992).

3. Pre-eclampsia was diagnosed when PIH was accompanied by proteinuria (Davey and MacGillivray 1988). Proteinuria was defined as the presence of more than a trace of protein in maternal urine samples examined on two or more visits to the antenatal clinic.

4. Glycosuria was used as an indicator of gestational diabetes (Sweet 1992) and was defined as the presence of more than a trace of glucose in maternal urine samples examined on two or more visits to the antenatal clinic.

5. Seropositivity for sexually-transmitted infections (WR/ $V D R L$ ) was determined from the cover of neonatal record charts for any mothers whose child had been admitted for neonatal care.

Self-reports of maternal age, reproductive history and obstetric morbidity were obtained at enrolment into the Birth to Ten study, using detailed interviews conducted during antenatal care or shortly after delivery. Among other questions, each mother was asked whether she had ever been pregnant before, and whether previous pregnancies had ended in miscarriages, terminations, premature- or still-births. Each mother was also asked whether she had experienced "swelling of your feet", "high blood pressure", "diabetes" or a "urinary infection" during her current (Birth to Ten) pregnancy, and whether she had ever been treated for "any sexually-transmitted disease". Self-reports of obstetric morbidity related to each of the five disorders (1. to 5. above) recorded on antenatal charts were thereby defined as: Oedema ("swelling of your feet" 1., 2. and 3. above); Hypertension ("high blood pressure" 1., 2. and 3. above); Pre-existing or gestational diabetes ("diabetes" - 4.) above; and Urinary tract infection (both past: "any sexually transmitted disease"; and present: urinary infection" -5 . above).

All results are presented as mean with standard errors (SEM) in parentheses. Standard Chi-squared $\left(\chi^{2}\right)$ and paired t-tests were used to assess the significance of the results (Sokal and Rohlf 1981). Ethical permission for the Birth to Ten study was obtained through a Human Subjects Clearance issued by the University of the Witwatersrand.

\section{Results}

Only $313(60.5 \%)$ of the 517 obstetric notes examined in the present study contained complete antenatal record cards. According to sociodemographic information archived in the Birth to Ten database, these obstetric notes belonged to women who 
had attained a significantly higher mean educational standard (5.70(1.73) South African Standard Grade) than women whose antenatal records were missing or incomplete (5.16(1.67) SA Standard Grade, $t=2.423, p<0.05$ ). However, there were no significant differences in maternal age, gravidity or access to medical insurance between the two groups. Using the clinical data abstracted from these 313 antenatal record cards it was possible to determine that $5.3 \%$ of the women exhibited pre-existing hypertension, and of the 295 women who made more than one visit to the antenatal clinic, $2.1 \%$ exhibited glycosuria, $12.7 \%$ developed PIH and $3.2 \%$ had proteinuria, while only $1.1 \%$ displayed the symptoms of preeclampsia (i.e. both PIH and proteinuria).

Fewer than $40 \%$ (200) of the 517 obstetric notes contained neonatal record cards, but there were no significant differences in the age, gravidity, educational standard attained or medical insurance status of mothers whose children had been admitted for neonatal care and those whose children had not. From the clinical data contained in these records it appeared that $7(4.4 \%)$ of the 160 women whose STD status was known were seropositive for one or more STDs

Due to the staggered nature of enrolment into Birth to Ten (Richter et al. 1995), only half (255) of the women examined in the present study had been interviewed about their obstetric morbidity. Those who were interviewed had made significantly more visits to their antenatal clinic $(6.6(2.81))$ than those who were not interviewed (5.78(3.26); $t=2.405, p<0.05$ ). However, there were no significant differences in the prevalence of hypertension, pre-eclampsia, glycosuria or STD infection between women who had been interviewed and those who had not.

To assess the reliability of self-reported reproductive histories, the self-reports of maternal age, gravidity and prior reproductive outcomes recorded in the antenatal record cards were compared to those collected during the Birth to Ten interviews. For the two continuous variables (maternal age and gravidity) the unreliability $\left(S_{r}{ }^{2}\right)$ of duplicate self-reports was calculated using the technique of Marks et al. (1988), where $S_{r}{ }^{2}=\Sigma d_{i}^{2} / 2 n$, the sum of the squared differences between selfreported data collected on two different occasions. The reliability coefficient, $R$, was then calculated as the proportion of the total sample variance $\left(s^{2}\right)$ that remained after subtracting unreliability $\left(R=s^{2}-S_{r}^{2} / s^{2}\right)$. The unreliability of selfreported maternal age was 1.16 years and the associated reliability coefficient $(R)$ was 0.993 . Likewise, the unreliability of self-reported gravidity was 0.25 pregnancies and the associated reliability coefficient $(R)$ was 0.810 . For the categorical variables (whether or not previous pregnancies ended in miscarriages, terminations, premature- or still-births) the reliability of maternal reports was calculated using Cohen's Kappa, which accounts for chance agreement between duplicate self-reports (see Casey et al. 1992). Reliability was only fair (Casey et al. 1992) for duplicate reports of previous premature births $(K=0.50)$, and previous pregnancies that ended in terminations, stillbirths and neonatal deaths $(K=0.48)$. Likewise, when asked to give the year in which their previous pregnancy took place, only $80.0 \%$ of multigravid mothers gave the same answer in their antenatal and Birth to Ten interviews.
To assess the validity of self-reported obstetric morbidity the proportion of accurately identified positive (sensitivity) and negative (specificity) diagnoses (based on data abstracted from hospital records: see Casey et al. 1992) for each of the five clinical conditions (pre-existing hypertension, PIH, pre-eclampsia, glycosuria and STD seropositivity) were calculated using self-reports of obstetric morbidity (oedema, hypertension, diabetes, urinary tract infection and treatment for STDs) collected during the Birth to Ten interviews. The results of these analyses are displayed in Table 1 , which shows that the apparent sensitivity of self-reports for most obstetric disorders was around $50 \%$. However, the diagnosed prevalence of all five obstetric conditions was too low to provide accurate estimates of sensitivity for all but one measure (oedema; with a sensitivity of $40 \%$ for pre-eclampsia) of self-reported obstetric morbidity. Nevertheless, estimates of specificity were generally high, particularly for self-reported hypertension and diabetes which had specificities of more than $95 \%$ for (preexisting or pregnancy-induced) hypertension or pre-eclampsia and glycosuria respectively. Since ostensibly high specificities are more likely to occur by chance for rarer diagnoses such as these, the lower specificity of commoner conditions, such as self-reported oedema for (pre-exiting or pregnancy-induced) hypertension or pre-eclampsia $(64.3 \%$ to $66.3 \%$ ) and self-reported urinary tract infection for STD seropositivity $(65.7 \%)$, provide a better indication of the limited specificity of self-reported obstetric morbidity.

\section{Discussion}

The impressive reliability of self-reported gravidity observed in the present study is similar to that described in England (Joffe and Grisso 1985) and the United States (Tilley et al. 1985), and supports the view that mothers accurately recall "significant" life events, such as pregnancy and childbirth (Hewson and Bennett 1987). However, self-reports of past miscarriages, terminations, premature- and still-births, were only modestly reliable. This suggests either that mothers were less willing to disclose unsuccessful outcomes of past pregnancies during interviews with Birth to Ten researchers than they were during consultations with antenatal staff, or that these outcomes constitute less "significant" life events, at least within the context of the Birth to Ten interviews (Joffe and Grisso 1985). Furthermore, the results of the present study confirm that the sensitivity and specificity of self-reported obstetric morbidity tend to be poor (Casey et al. 1992). In fact, since hospital records are often incomplete (Tilley et al. 1985; Laurell et al. 1994; Harris et al. 1997), inconsistent (Joffe and Grisso 1985; Harris et al. 1997), inaccurate (Hewson and Bennett 1987), and difficult to abstract (Horwitz and Yu 1984; Harris et al. 1997), it is likely that the sensitivity of self-reported obstetric morbidity might have been even lower than that estimated in the present study.

This does not necessarily mean that the mothers themselves were responsible for the limited validity of their self-reported obstetric morbidity. To start with, some of the self-reported symptoms examined in the present study provide somewhat less than perfect indicators of the clinical conditions diagnosed. For example, oedema may not always accompany preexisting hypertension, PIH or pre-eclampsia (Davey and MacGillivray 1988), while urinary tract infection and previous treatment for STDs might not accurately reflect current 
STD seropositivity (Essén et al. 1994). Nevertheless, assuming that the hospital records were carefully compiled and accurately abstracted (a generous assumption at best: Ellison et al. 1997), the self-reports of hypertension and diabetes should have provided reasonable estimates of clinically diagnosed hypertensive disorders and glycosuria. In fact, these self-reported conditions had the highest sensitivities and specificities observed in the present study, although the self-reports of high blood pressure appeared to be insensitive for PIH.

While it is tempting to conclude that the limited accuracy of self-reported obstetric morbidity might partly reflect the modest cducational attainment of women in Soweto, the Birth to Ten mothers whose obstetric notes contained antenatal record cards had actually attained a slightly higher level of schooling than those whose notes did not. Indeed, comparably (in)accurate self-reports of obstetric morbidity have been observed among ostensibly better educated mothers in the United States (Tilley et al. 1985), and even those with some tertiary education (Casey et al. 1992). This suggests that mothers everywhere are generally unable or unwilling to divulge information about their obstetric health. In part this might reflect the perceived sensitivity of past and current medical events (Hewson and Bennett 1987), in part the inadequacy of communication between clinicians and mothers (Tilley et al. 1985; Matshidze et al. 1998). In the present study, for example, the large proportion of mothers who answered "don't know" exacerbated the limited specificity of self-reported urinary tract infections for diagnoses of STD infection (see Table 1). Likewise, all but one of the mothers who had been routinely tested for STDs during antenatal care reported that they did not know whether they had ever been treated for STDs. While it is possible that all of the mothers who tested negative for STDs during antenatal care were neither consulted beforehand nor informed thereafter, it is also likely that the social stigma attached to STD (Casey et al. 1992) dissuaded STD-positive mothers from disclosing this information to researchers who were uninvolved with their medical care.

Either way, the limited validity of self-reported obstetric morbidity inevitably undermines the clinical utility of any information obtained. It might therefore seem appropriate to avoid using self-reports of maternal morbidity wherever possible. This is often impractical, for a number of reasons. Maternal medical records and obstetric notes from previous pregnancies are often unavailable for consultation by antenatal clinic staff, even where record-keeping facilities are good (Lovell et al. 1987). Likewise, clinicians in the delivery ward can not refer to the medical records of mothers who did not attend antenatal care or those who present for delivery without medical records (Elbourne et al. 1987; Laurell et al. 1994). In view of the large number of obstetric notes examined in the present study which did not contain antenatal record cards, it appears that staff in the delivery ward at Baragwanath Hospital were often unable to consult the antenatal records of Birth to Ten mothers. Whatever the reason, there seems little alternative but to rely on maternal reports of obsteric morbidity for those mothers who find themselves in similar circumstances during clinical consultations.

It is therefore clearly important to improve the validity of self-reported obstetric morbidity, through better communication between antenatal clinicians and the mothers in their care (Elbourne et al. 1987; Matshidze et al. 1998) and by ensuring greater access to education and health information for women (Shah et al. 1993). For this reason mothers should be provided with their own medical records, or at least a summary thereof, along the lines of the "Home-based Maternal Records" advocated by the World Health Organisation (WHO 1994). These records have the twin benefits of facilitating access to each mother's past medical history (wherever she may be), and empowering mothers as active consumers (rather than passive recipients) of health care services (Shah et al. 1993). Research conducted at Alexandra Health Centre and University Clinic in Johannesburg found that patient-held records not only reduced the workload of medical records staff, but also reduced the amount of time required to register patients and increased the proportion of consultations in which clinicians had access to patients' previous medical records (Daviaud et al. 1996).

\section{Acknowledgements}

The authors would like to thank the Birth to Ten Research Assistants and study participants who made this project possible. Birth to Ten is a multidisciplinary longitudinal study which receives financial and logistic support from: the Urbanisation and Health Programme of the Medical Research Council; the Anglo-American and DeBeers Chairman's Fund Educational Trust; the Centre for Science Development of the Human Sciences Research Council; the University of the Witwatersrand; the Institute for Behavioural Sciences at the University of South Africa; and numerous corporate sponsors. George Ellison was supported by a Scientific Exchange grant from the Royal Society and a research grant from the Simon Population Trust.

\section{References}

CASEY R; RIECKHOFF M; BEEBE SA ET AL 1992: Obstetric and perinatal events: The accuracy of maternal report. Clin Pediatr 31: 200-204

CARROLL S; CHARD T; LLOYD DSL ET AL 1988: Preparation of risk cards using a computerised obstetric information system. J Obstet Gynecol 8: 222-227

DAVEY D A, MACGILLIVRAY I 1988. The classification and definition of the hypertensive disorders of pregnancy. Am J Obstet Gynecol 158: 892-898

DAVIAUD E; CEBEKHULU Q; MONIEZ V 1996: Patient-retained records - experience at the Alexandra Health Centre. S Afr Med J 86: 986-987.

ELBOURNE D; RICHARDSON M; CHALMERS I ET AL 1987: The Newbury Maternity Care Study: a randomized controlled trial to assess a policy of women holding their own obstetric records. Br J Obstet Gynaecol 94: 612-619

ELLISON GTH; RICHTER LM; DE WET T ET AL 1997: The reliability of hand-written and computerised records of birth data collected at Baragwanath Hospital in Soweto. Curationis 20: $36-40$

ESSÉN B; LAURELL L; PEÑA R ET AL 1994: Antena- 
tal cards - What should they contain? J Trop Pediatr 40: 130132

FOX NL; SEXTON M; HEBEL JR ET AL 1989: The reliability of self-reports of smoking and alcohol consumption by pregnant women. Addiction Behav 14: 187-195

HALL MH; CHNG PK; MACGILLIVRAY I 1980: Is routine antenatal care worthwhile? Lancet 2: 78-80

HARRIS HE; ELLISON GTH; HOLLIDAY M ET AL 1997: Methodological considerations in the design of an obstetric database abstracted from medical records. Meth Inf Med 36: 191-200.

HEWSON D \& BENNETT A 1987: Childbirth research data: Medical records or women's reports? Am J Epidemiol 125: 484-491

HORWITZ RI \& YU EC 1984: Assessing the reliability of epidemiologic data obtained from medical records. J Chr Dis 37: 825-831

HUTCHINGS L; ELLISON GTH \& JASS P 2000: The impact of free health care on antenatal attendance and subsequent birth outcome at Alexandra Health Centre in Johannesburg. Ann Hum Biol 28: 107-8

JOFFE M \& GRISSO JA 1985: Comparison of ante-natal hospital records with retrospective interviewing. J Biosoc Sci 17: $113-119$

LAURELL L; ESSÉN B \& LAURELL L ET AL 1994: A study of the use of the Nicaraguan antenatal card. $J$ Trop Pediatr 40: 133-136

LOVELL A; ZANDER LI \& JAMES CE ET AL 1987: The St Thomas's Hospital maternity case notes study: A randomised controlled trial to assess the effects of giving expectant mothers their own maternity case notes. Paediatr Perinat Epidemiol 1: 57-66

MARKS GC; HABICHT J-P \& MUELLER WH 1988. Reliability, dependability, and precision of anthropometric measurements. The second National Health and Nutrition Examination Survey 1976-1980. Am J Epidemiol 130: 578-587

MATSHIDZE KP; RICHTER LM \& ELLISON GTH ET AL 1998: Caesarean section rates in South Africa: Evidence of bias among different 'Population Groups'. Ethn Health 3: 71-79.

MATI KG 1994: Antenatal care. In: Nasah; Mati, Kasonde (eds) Contemporary Issues in Maternal Health Care in Africa. Harwood Academic Publishers, Luxembourg.

MCCOY D 1996: Free health care for pregnant women and children under six in South Africa: An impact assessment. Health Systems Trust, Durban.

PEOPLES-SHEPS MD; KALSBEEK WD \& SIEGEL E ET AL 1991: Pre-natal records: A national survey of content. Am J Obstet Gynecol 164: 514-21.
RICHTER LM; YACH D \& CAMERON N ET AL 1995: Enrolment into Birth to Ten (BTT): population and sample characteristics. Paediatr Perinat Epidemiol 9: 109-120

SHAH PM; SELWYN BJ \& SHAH K ET AL 1993: Evaluation of the home-based maternal record: a WHO collaborative study. Bull WHO 71: 535-548.

SOKAL RR \& ROHLF FJ 1981: Biometry. WH Freeman and Co, San Francisco.

SWEET BR 1992: Baillière's Midwives' Dictionary (8th Edition). Baillière Tindall, London

TILLEY BC; BARNES AB \& BERGSTRALH E ET AL 1985: A comparison of pregnancy history recall and medical records. Implications for retrospective studies. Am J Epidemiol 121: $269-281$

VENTURA SJ; MARTIN JA \& TAFFEL SM ET AL 1994: Advance report of final natality statistics, 1992. Month Vital Stat Rep 43: 1-88

WHO (World Health Organisation) 1994: Home-based Maternal Records. World Health Organisation, Geneva

YACH D; CAMERON N \& PADAYACHEE N ET AL 1991: Birth to ten: child health in South Africa in the 1990s. Rationale and methods of a birth cohort study. Paediatr Perinat Epidemiol 5: 211-233 
Table 1. The sensitivity and specificity of questions relating to self-reported obstetric morbidity when compared to diagnoses of five obstetric conditions abstracted from antenatal, obstetric and neonatal records at Baragwanath Hospital.

Sensitivity (\%): $\quad$ [number of positive cases correctly identified bv maternal self-reports] $\times 100$

[total number of positive cases diagnosed in hospital records]

Clinical measures of obstetric morbidity:

\begin{tabular}{llllll}
\hline & $\begin{array}{l}\text { Pre-existing } \\
\text { hypertension }\end{array}$ & $\begin{array}{l}\text { Pregnancy-induced } \\
\text { hypertension }\end{array}$ & Pre-eclampsia & Glycosuria & $\begin{array}{l}\text { STD } \\
\text { infection }\end{array}$ \\
\hline $\begin{array}{l}\text { Self-reports: }{ }^{1} \\
\text { Hypertension }\end{array}$ & $66.7(2 / 3)$ & $-(0 / 10)$ & $-(0 / 0)$ & & \\
Oedema & $66.7(2 / 3)$ & $40.0(4 / 10)$ & $-(0 / 0)$ & & \\
Diabetes & & & & \\
$\begin{array}{l}\text { Urinary tract } \\
\text { infection }\end{array}$ \\
$\begin{array}{l}\text { Treatment } \\
\text { for STD }\end{array}$
\end{tabular}

'The number of mothers who correctly reported the presence of each diagnosed condition excludes those who responded "don't know"

Specificity (\%): [number of negative cases correctlv identified bv maternal self-reports] $\times 100$

[total number of negative cases diagnosed in hospital records]

Clinical measures of obstetric morbidity:

\begin{tabular}{llllll}
\hline & $\begin{array}{l}\text { Pre-existing } \\
\text { hypertension }\end{array}$ & $\begin{array}{l}\text { Pregnancy-induced } \\
\text { hypertension }\end{array}$ & Pre-eclampsia & Glycosuria & $\begin{array}{l}\text { STD } \\
\text { infection }\end{array}$ \\
\hline $\begin{array}{l}\text { Self-reports: } \\
\text { Hypertension }\end{array}$ & $97.8(87 / 89)$ & $95.9(71 / 74)$ & $96.4(81 / 84)$ & & \\
Oedema & $66.3(59 / 89)$ & $64.9(48 / 74)$ & $64.3(54 / 84)$ & & \\
Diabetes & & & & $98.8(82 / 83)$ & \\
$\begin{array}{l}\text { Urinary tract } \\
\text { infection }\end{array}$ & & & & \\
$\begin{array}{l}\text { Treatment } \\
\text { for STD }\end{array}$ & & & \\
\hline
\end{tabular}

'The number of mothers who correctly reported the absence of each diagnosed condition excludes those who responded "don't know"

${ }^{2}$ The lower denominator reflects the smaller number of mothers who provided self-reports of treatment for STD. 